\title{
Characterisation and tracking changes of morphological characteristics in honey bee, Apis mellifera, colonies
}

\author{
H.F. Abou-Shaara, M.E. Ahmed \\ Plant Protection Department, Faculty of Agriculture, Damanhour University, Damanhour, Egypt
}

\begin{abstract}
Measuring morphological characteristics of honey bee, Apis mellifera, at different times is important to assess the degree of race purity, to predict colony productivity, and to understand environmental impacts on honey bees. The study aims to characterise current honey bees of Northwest Egypt, namely El-Behera governorate, and to track occurred changes to their morphological characteristics since 2007. Samples of honey bee workers were collected from four districts in ElBehera governorate. Nine body and six wing characteristics were measured. Morphological characteristics of honey bees belonging to these districts were previously measured during 2007. To track changes, a comparison between new (2014) and previous (2007) measurements of morphological characteristics was done. The current bees of El-Behera are slightly larger than those of 2007, emphasising no reduction in colonies productivity. There is evidence that environmental factors have not caused much stress on the colonies since 2007. The results of this study are useful in providing understanding of the current state of bees in Egypt, and the likely improvement of future beekeeping.
\end{abstract}

Correspondence: Hossam Farag Abou-Shaara, Plant Protection Department, Faculty of Agriculture, Damanhour University, P.0. Box 22516, Damanhour, Egypt.

E-mail: entomology_20802000@yahoo.com ; hossam.farag@agr.dmu.edu.eg

Key words: Honey bees; Apis mellifera; morphometry; cubital index.

Acknowledgements: thanks are given to Mr. Hany Farag, Eng. Elsayed Awad and Eng. Nasr El-Halawany for their kind help during samples collection. Thanks are also presented to Dr. John B. McMullan, Malahide, County Dublin, Ireland for the revision and his valuable comments on the manuscript, and to Prof. Bruno Rossaro, Università degli Studi di Milano for his kind help in the statistical analysis and useful comments on the manuscript.

Received for publication: 23 February 2015.

Revision received: 20 August 2015.

Accepted for publication: 22 August 2015.

(C) Copyright H.F. Abou-Shaara and M.E. Ahmed., 2015

Licensee PAGEPress, Italy

Journal of Entomological and Acarological Research 2015; 47:5120

doi:10.4081/jear.2015.5120

This article is distributed under the terms of the Creative Commons Attribution Noncommercial License (by-nc 3.0) which permits any noncommercial use, distribution, and reproduction in any medium, provided the original author(s) and source are credited.

\section{Introduction}

Morphological characteristics of honey bees, Apis mellifera, are very important to follow changes of honey bee colonies over time (AbouShaara et al., 2012b), to investigate hybridisation with other subspecies (Radloff et al., 2003), to characterise honey bee subspecies (Meixner et al., 2007), to study symmetry of body parts and to discriminate between subspecies (Abou-Shaara \& Al-Ghamdi, 2012). Morphological studies on honey bees can be divided into two basic categories: standard (using wing and body characteristics) and geometric morphometrics (using coordinates of wing points). Recently these two categories have been intensively reviewed by Abou-Shaara et al. (2013) and Abou-Shaara (2013).

It is well known that different morphological characteristics of honey bees (e.g., wings and legs) are correlated with honey production (Milne \& Pries, 1984; Waddington, 1989; Kolmes \& Sam, 1991; Edriss et al., 2002; Mostajeran et al., 2006). Basically, bees with large body characteristics are better than those with smaller ones in regard to honey production, but in regard to tolerance to thermal stress the opposite has been found (Abou-Shaara et al., 2012a). Hence, measuring morphological characteristics over time is important to detect the occurrence of any changes to honey bee colonies in regard to subspecies purity, colonies productivity, and tolerance to environmental factors.

In the El-Behera governorate, Egypt, Abou-Shaara et al. (2012b) have studied morphological characteristics of managed honey bee colonies belonging to different districts during two successive years 2006 and 2007. They found a decline in most measured characteristics in 2007 compared to 2006. It has been hypothesised that the decline in morphological characteristics would be continued over time. The objectives of this study are therefore, to test this hypothesis, by the characterisation of current honey bees of the El-Behera governorate, and tracking the actual changes to morphological characteristics.

\section{Materials and methods}

\section{Sampling}

Samples of honey bee workers were collected during autumn 2014 from 4 districts (Damanhour, El-Mahmoudia, El-Dalangat and Hosh Esa) as shown in Figure 1. Total of 32 colonies were sampled (8 colonies/apiary per district), and 20 workers were collected from each colony (total of 640 workers). The collected samples were kept in ethyl alcohol $70 \%$ till analysis.

\section{Taking measurements}

Collected workers were dissected using forceps to separate heads, wings and legs. The separated body parts were then scanned using 
Canon scanner (k10352, CanoScan LiDE 110, Vietnam) at 1200 dpi. The images obtained were subsequently analysed in Adobe Photoshop ${ }^{\circledR}$ (Adobe Systems Inc., San Jose, CA, USA) according to Abou-Shaara et al. (2011) to measure: head width (HW), fore wing length (FWL) and width (FWW), hind wing length (HWL) and width (HWW), femur length (FL), tibia length (TL), and basetarsus length (BL) and width (BW), and cubital index (CI) which was calculated as distance A/distance B. Some wing angles (A4, D7, J16, K19 and Q21) were measured using image 1.46 program.

\section{Characterisation}

Firstly, a principal component analysis was carried out to compare the four districts using $R$ package 3.2.1. Then means of measured characteristics for studied districts were compared by Duncan s multiple range ( $\alpha=0.05)$ using SAS 9.1.3 (2004). The measured characteristics for the studied districts were then compared with means presented in Abou-Shaara (2009) for native honey bees of Egypt (Apis mellifera lamarckii), Carniolan honey bees (A.m. carnica) and Italian honey bees (A.m.ligustica).

\section{Track changes of measured characteristics}

To track changes of honey bee characteristics at El-Behera governorate, morphological characteristics for the studied districts were compared with the most recent data of morphological characteristics during 2007 (Abou-Shaara et al., 2012b) for the same districts. A principal component analysis starting from means of 2007 and 2014 was performed to compare years using $\mathrm{R}$ package 3.2.1.

\section{Results}

\section{Characterisation}

Significant differences were found among studied districts in the measured characteristics. Only HW showed significant differences among all the studied districts while the other characters showed significant differences only between 2 or 3 districts. The highest means for 6 characters were found in colonies belonging to Damanhour district while the other districts had the highest means

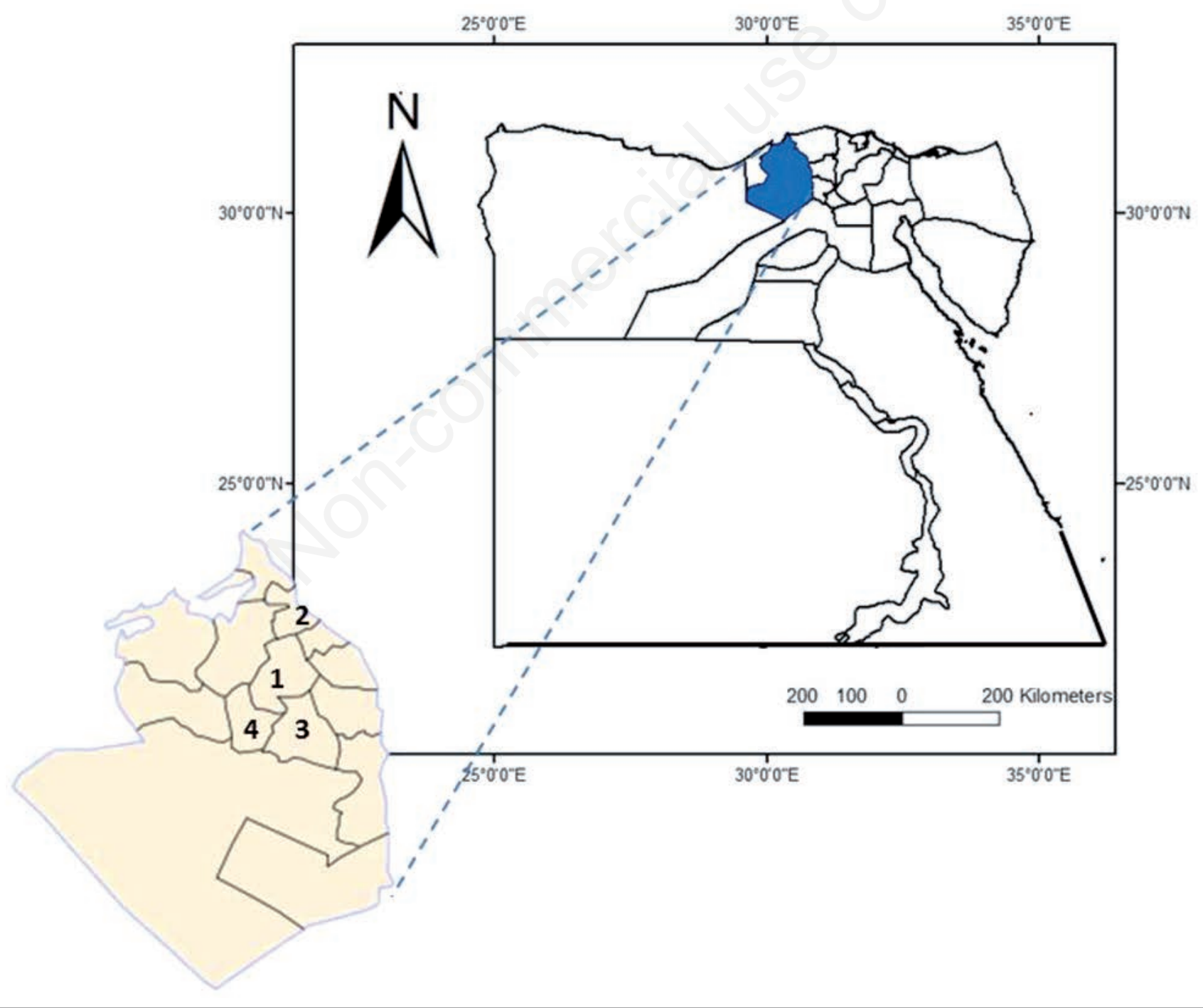

Figure 1. Location of El-Behera governorate in Egypt (located between 30 36' 36” $\mathrm{N}$ and 30 25'48” E with total area of $9826 \mathrm{~km}^{2}$ ), and studied districts (1, Damanhour; 2, El-Mahmoudia; 3, El-Dalangat; 4, Hosh Esa). 
only for a lower number of characters per district (Table 1). The overall means for measured characteristics are higher than those of native honey bees of Egypt (A.m. lamarckii) by $0.45,0.26,0.05$ and $0.62 \mathrm{~mm}$ for FWL, FWW, BL and CI, respectively. Carniolan honey bees (A.m. carnica) have higher means than El-Behera bees by 0.49 , $0.15,0.57,0.18,0.41$ and $0.06 \mathrm{~mm}$ for FWL, FWW, HWL, HWW, BL and BW, re spectively. Italian honey bees (A.m.ligustica), also, have higher means than El-Behera bees by $0.51,0.18$ and $0.07 \mathrm{~mm}$ for FWL, FWW and BL, respectively. El-Behera honey bees have higher means than Carniolan and Italian honey bees only in CI value, measuring 0.43 and 0.32 , respectively.

When HW was plotted against TL using SYSTAT 13 (Figure 2), a separation for studied colonies was obtained with few overlapping. However, it was not possible to separate the studied colonies into well distrinct clusters when all characters were included in a principal component analysis, even if some separation of cluster is apparent (Figure 3). The overlap between colonies belonging to the studied districts suggests a high degree of hybridisation.

\section{Track changes of measured characteristics}

As presented in Table 2, FWW, FL and TL showed increases in all districts while BL showed decrease in all districts. CI showed decrease in Damanhour only. The other characteristics showed increase only in Damanhour except HWW which increased only in El-Dalangat. The increase ranged from 0.03 to 0.54 while the decrease ranged from 0.01 to 0.4 . The increasing in characteristics relate to body size reflect that honey bees of El-Behera are currently larger than the past (Figure 4).

As shown in Figure 5, five characteristics showed increases in their overall means during 2014 compared to 2007 (namely; FWW, FL, TL, and BW, and CI) with difference of $0.11,0.07,0.1$ and $0.01 \mathrm{~mm}$, and 0.2 , respectively. Three characteristics (FWL, HWL and BL) showed decreases in 2014 compared to 2007 of $0.04,0.02$ and $0.09 \mathrm{~mm}$ while HWW showed no change between 2007 and 2014. Principal component analysis emphasised a clear separation between means of 2007 and
2014 (Figure 6), confirming some modification of morphometric characteristics of populations in time.

\section{Discussion}

\section{Characterisation}

The measured means of El-Behera bees from different districts showed that current bees are larger than native Egyptian bees but

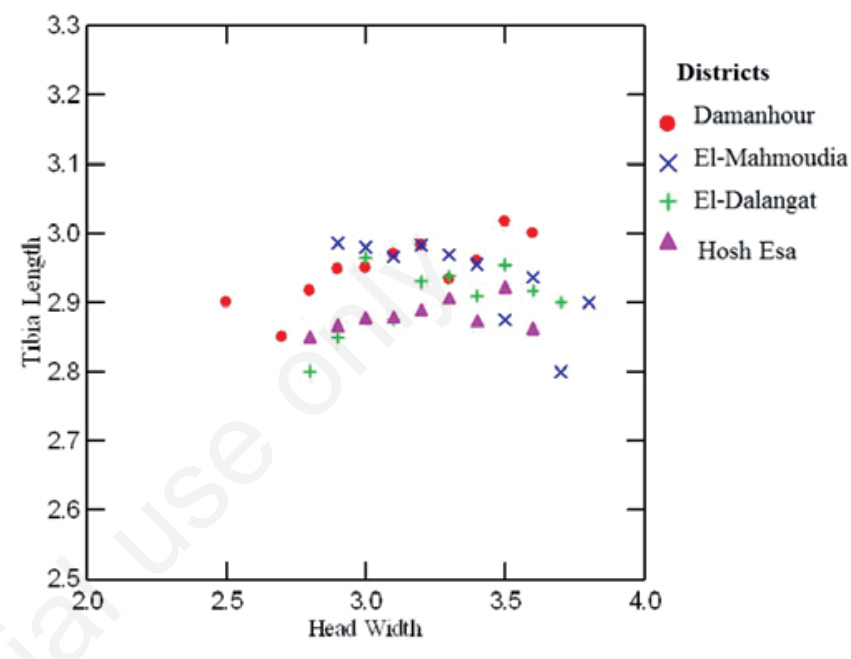

Figure 2. Means of tibia length against means of head width, grouped by studied districts.

Table 1. Means \pm standard deviation of measured characteristics for studied districts. All characteristics are in mm except angles in degrees, and cubital index without units.

\begin{tabular}{|c|c|c|c|c|c|}
\hline \multirow[t]{2}{*}{ Characteristics } & \multicolumn{4}{|c|}{ Districts } & \multirow[b]{2}{*}{ Overall mean } \\
\hline & Damanhour & El-Mahmoudia & El-Dalangat & Hosh Esa & \\
\hline Head width & $3.09 \pm 0.21^{\mathrm{d}}$ & $3.22 \pm 0.21^{\mathrm{c}}$ & $3.32 \pm 0.19^{\mathrm{a}}$ & $3.27 \pm 0.18^{b}$ & $3.22 \pm 0.09$ \\
\hline Fore wing length & $8.74 \pm 0.20^{\mathrm{a}}$ & $8.70 \pm 0.17^{\mathrm{ab}}$ & $8.67 \pm 0.19^{\mathrm{bc}}$ & $8.64 \pm 0.19^{c}$ & $8.68 \pm 0.04$ \\
\hline Fore wing width & $3.06 \pm 0.09^{\mathrm{a}}$ & $3.06 \pm 0.10^{\mathrm{a}}$ & $3.02 \pm 0.10^{b}$ & $3.02 \pm 0.11^{b}$ & $3.04 \pm 0.02$ \\
\hline Hind wing length & $6.09 \pm 0.20^{b}$ & $6.08 \pm 0.17^{\mathrm{b}}$ & $6.14 \pm 0.15^{\mathrm{a}}$ & $6.01 \pm 0.21^{\mathrm{c}}$ & $6.08 \pm 0.05$ \\
\hline Hind wing width & $1.70 \pm 0.13^{b}$ & $1.75 \pm 0.18^{\mathrm{a}}$ & $1.78 \pm 0.13^{\mathrm{a}}$ & $1.77 \pm 0.18^{a}$ & $1.75 \pm 0.03$ \\
\hline Femur length & $2.34 \pm 0.13^{\mathrm{a}}$ & $2.32 \pm 0.14^{\mathrm{a}}$ & $2.25 \pm 0.17^{b}$ & $2.25 \pm 0.12^{b}$ & $2.29 \pm 0.04$ \\
\hline Tibia length & $2.95 \pm 0.11^{\mathrm{a}}$ & $2.96 \pm 0.10^{\mathrm{a}}$ & $2.92 \pm 0.11^{\mathrm{b}}$ & $2.88 \pm 0.09^{c}$ & $2.92 \pm 0.03$ \\
\hline Basetarsus length & $2.01 \pm 0.11^{b}$ & $2.02 \pm 0.10^{b}$ & $1.98 \pm 0.09 \mathrm{c}$ & $2.04 \pm 0.09^{\mathrm{a}}$ & $2.01 \pm 0.02$ \\
\hline Basetarsus width & $1.15 \pm 0.10^{\mathrm{a}}$ & $1.12 \pm 0.07^{\mathrm{b}}$ & $1.09 \pm 0.10^{c}$ & $1.10 \pm 0.06^{\mathrm{c}}$ & $1.11 \pm 0.02$ \\
\hline Ditsance A & $0.51 \pm 0.05^{b}$ & $0.52 \pm 0.06^{\mathrm{b}}$ & $0.51 \pm 0.06^{\mathrm{b}}$ & $0.55 \pm 0.06^{a}$ & $0.52 \pm 0.02$ \\
\hline Distance B & $0.19 \pm 0.03^{\mathrm{a}}$ & $0.19 \pm 0.05^{\mathrm{a}}$ & $0.19 \pm 0.04^{\mathrm{a}}$ & $0.19 \pm 0.04^{\mathrm{a}}$ & $0.19 \pm 0.00$ \\
\hline Cubital index & $2.79 \pm 0.97^{\mathrm{a}}$ & $2.96 \pm 1.11^{\mathrm{ab}}$ & $2.95 \pm 1.17^{\mathrm{ab}}$ & $3.12 \pm 1.17^{\mathrm{a}}$ & $2.95 \pm 0.13$ \\
\hline Angle A4 & $34.56 \pm 3.27^{\mathrm{a}}$ & $35.20 \pm 3.30^{\mathrm{a}}$ & $35.14 \pm 3.26^{\mathrm{a}}$ & $33.25 \pm 2.51^{\mathrm{b}}$ & $34.53 \pm 0.90$ \\
\hline Angle D7 & $93.72 \pm 4.18^{b}$ & $92.50 \pm 4.53^{\mathrm{c}}$ & $93.24 \pm 4.49^{\mathrm{bc}}$ & $94.77 \pm 3.82^{\mathrm{a}}$ & $93.55 \pm 0.95$ \\
\hline Angle J16 & $94.84 \pm 6.73^{b}$ & $96.99 \pm 6.76^{\mathrm{a}}$ & $95.09 \pm 6.39^{b}$ & $95.25 \pm 6.23^{b}$ & $95.54 \pm 0.97$ \\
\hline Angle K19 & $79.01 \pm 4.50^{\mathrm{a}}$ & $77.98 \pm 4.07^{\mathrm{b}}$ & $77.70 \pm 4.05^{b}$ & $77.18 \pm 4.15^{b}$ & $77.96 \pm 0.76$ \\
\hline Angle Q21 & $35.12 \pm 2.66^{\mathrm{a}}$ & $34.16 \pm 2.64^{c}$ & $34.33 \pm 2.78^{\mathrm{bc}}$ & $34.77 \pm 2.76^{\text {ba }}$ & $34.59 \pm 0.43$ \\
\hline
\end{tabular}

Means followed by the same letter in the same row are not significantly different according to Duncan s multiple range ( $\alpha=0.05)$. 
smaller than Carniolan and Italian honey bees. This could be attributed mainly to the uncontrolled hybridisation among managed colonies of El-Behera due to migratory beekeeping activity, especially since the colonies are distributed in relatively small geographical areas. It is known that hybrids of Egyptain X Carniolan honey bees are common throughout Egypt, due to the importation of large numbers of Carniolan honey bees mainly between 1930 to 1940 (Sheppard et al., 2001). Other honey bee subspecies were also imported to Egypt (Page et al., 1981), mainly Italian honey bees. This explains why the measured characteristics are larger than those of native bees and smaller than Carniolan or Italian honey bees.

\section{Track changes of measured characteristics}

The current bees of El-Behera are slightly larger than in the past (2007) and only few decreases happened in some characteristics. Unlike the results obtained by Abou-Shaara et al. (2012b), that found that most of measured characteristics of El-Behera districts showed a decrease in 2007 compared to 2006 . The results of this study prove that the reduction in morphological characteristics of El-Behera honey bees was temporary. Various studies highlighted the impacts of environmental conditions (Milne et al., 1986), hybridisation with other honey bee subspecies (Garnery et al., 1998) and migratory beekeeping (Marghitas et al., 2008) on morphology of honey bees. Thus,



Figure 3. Principal component analysis results for honey bee colonies of studied districts (A, Damanhour; B, El-Mahmoudia; C, El-Bostan; D, Hosh Esa).



Figure 4. Variables used in principal component analysis for honey bee colonies of studied districts (A, Damanhour; B, ElMahmoudia; C, El-Bostan; D, Hosh Esa) and studied characteristics. FWL, fore wing length; FWW, fore wing width; HWL, hind wing length; HWW, hind wing widt; FL, femur length; TL, tibia length; BL, basetarsus length; BW, basetarsus width; DistA, distance A; DistB, distance B; CI, cubital index.

Table 2. Differences between means of morphological characteristics for studied districts during 2007 and 2014 . The values are in mm except for cubital index, and the values were calculated as (2007 means - 2014 means).

Characteristics Districts Damanhour Bl-Mahmoudia Hosh

\begin{tabular}{lcccc} 
Fore wing length & 0.03 & 0.02 & 0.05 & 0.09 \\
Fore wing width & -0.08 & -0.18 & -0.06 & 0.12 \\
\hline Hind wing length & -0.04 & 0.02 & 0.01 & 0.1 \\
Hind wing width & 0.01 & 0.01 & -0.01 & 0.01 \\
\hline Femur length & -0.10 & -0.10 & -0.04 & -0.03 \\
Tibia length & -0.16 & -0.12 & -0.12 & -0.03 \\
\hline Basetarsus length & 0.06 & 0.12 & 0.14 & 0.05 \\
Basetarsus width & -0.08 & 0.00 & 0.02 & 0.01 \\
\hline Cubital index & 0.40 & -0.15 & -0.50 & -0.54 \\
\hline
\end{tabular}




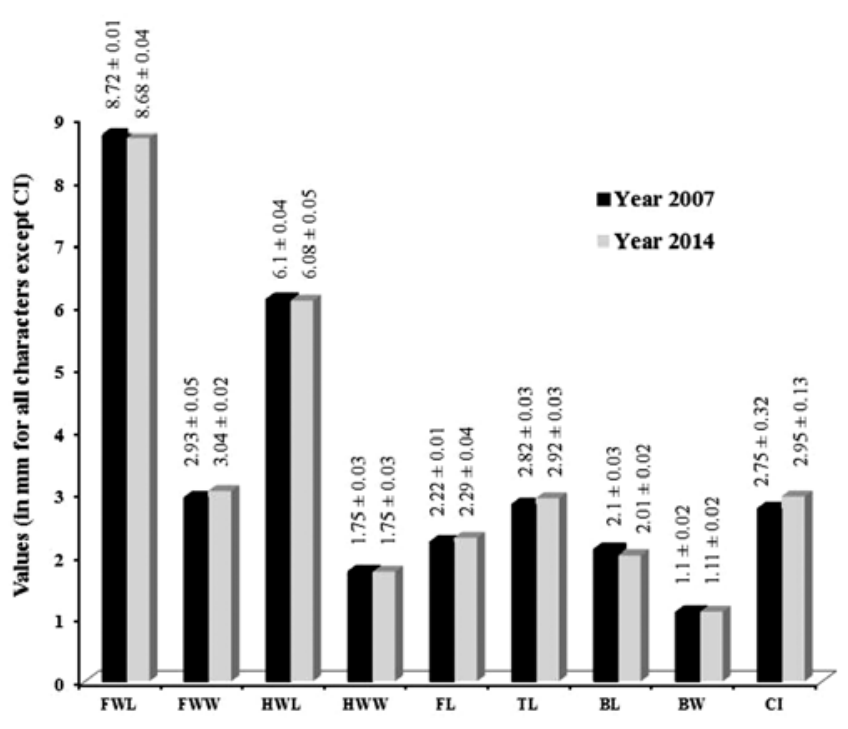

Figure 5. Overall means for 2007 and 2014. FWL, fore wing length; FWW, fore wing width; HWL, hind wing length; HWW, hind wing widt; FL, femur length; TL, tibia length; BL, basetarsus length; BW, basetarsus width; CI, cubital index.

the uncontrolled hybridisation between managed honey bee colonies due to beekeeper practices including migratory beekeeping could be the main reason behind the slight increase in morphological characteristics. Also, it may be that new hybrid queens were recently introduced to El-Behera and widely used. The previous investigations by Kolmes \& Sam (1991), Edriss et al. (2002), and Mostajeran et al. (2006) have highlighted the positive correlation between morphological characteristics and colony productivity. Thus, it could say that colonies productively have not impacted since 2007 . It could be expected that the current bees with slightly larger characteristics than the past are good in regard to colony productivity.

\section{Conclusions}

Current honey bees of El-Behera are slightly larger than those of 2007. High degree of hybridisation in studied colonies was found. No major changes have happened to current bees since 2007, and colonies productivity is expected to be the same as 2007. Measuring the morphological characteristics in different years is advisable to follow the changes in time that have occurred to honey bees.

\section{References}

ABOU-SHAARA H.F., 2009 - Morphometrical, biological and behavioral studies on some honey bee races at El-Beheira Governorate. - Msc Thesis, Faculty of Agriculture, Alexandria University, Egypt, 97 pp. ABOU-SHAARA H.F., 2013 - Wing venation characteristics of honey bees. - J. Apic. 28: 79-86.

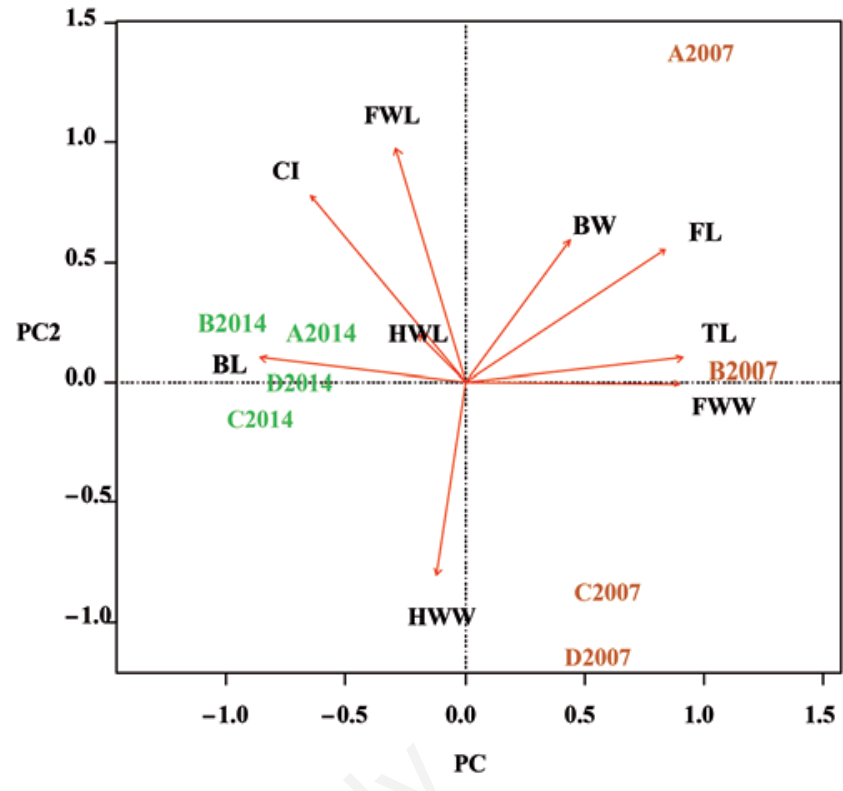

Figure 6. Comparison between different years. Principal component analysis for honey bee colonies of studied districts (A, Damanhour; B, El-Mahmoudia; C, El-Bostan; D, Hosh Esa) during 2007 and 2014. FWL, fore wing length; FWW, fore wing width; HWL, hind wing length; HWW, hind wing widt; FL, femur length; TL, tibia length; BL, basetarsus length; BW, basetarsus width; CI, cubital index.

ABOU-SHAARA H.F., AL-GHAMDI A.A., 2012 - Studies on wings symmetry and honey bee races discrimination by using standard and geometric morphometrics. - Biotechnol. Animal Husb. 28: 575-584.

ABOU-SHAARA H.F., AL-GHAMDI A.A., MOHAMED A.A., 2012a Tolerance of two honey bee races to various temperature and relative humidity gradients. - Env. Exp. Biol. 10: 133-138.

ABOU-SHAARA H.F., AL-GHAMDI A.A., MOHAMED A.A., 2013 - Body morphological characteristicistics of honey bees. - Agricultura 10: 45-49.

ABOU-SHAARA H.F., DRAZ K.A., AL-AW M., EID K., 2011 - Simple method in measuring honey bee morphological characteristics. Poster in $42^{\text {nd }}$ International Apicultural Congress-Apimondia, 21 to 25 September, Buenos Aries, Argentina, pp 222.

ABOU-SHAARA H.F., DRAZ K.A., AL-AW M., EID K., 2012b - Stability of honey bee morphological characteristics within open populations. - U. Bee J. 12: 31-37.

EDRISS M.A., MOSTAJERAN M., EBADI R., 2002 - Correlation between honey yield and morphological traits of honey bee in Isfahan. - J. Sci. Tech. Agri. Nat. Res. 6: 91-103.

GARNERY L., FRANCK P., BAUDRY E., VAUTRIN D., COMUET J.M., SOLIGNAC M., 1998 - Genetic diversity of the west European honey bee (Apis mellifera mellifera) and (Apis mellifera iberica). Mitochondrial DNA. - Genet. Sel. Evol. 30: 31-47.

KOLMES S.A., SAM Y., 1991 - Relationships between sizes of morphological features in worker honeybees (Apis mellifera). - J. New York Entomol. Soc. 99:684-690.

MARGHITAS A.L., PANITI-TELEKY O., DEZMIREAN D., MARGAOAN R., BOJAN C., COROIAN C., LASLO L., MOISE A., 2008 - Morphometric differences between honey bees (Apis mellifera carpatica) Populations from Transylvanian area. - Zootehnie Si Biotehnologii 41:309-315.

MEIXNER D.M., MIROSLAW W., JERZY W., FUCHS S., NIKOLAUS K., 2007 
- Apis mellifera mellifera range in eastern Europe- morphometric variation and determination of its limits. - Apidologie 38:1-7.

MILNE C.P., HELLMICH R.L., PRIES K.J., 1986 - Corbicular size in workers from honey bee lines selected for high or low pollen hoarding. - J. Apic. Res. 25: 50-52.

MILNE C.P., PRIES K.J., 1984 - Honeybee corbicular size and honey production. - J. Apic. Res. 23: 11-14.

MOSTAJERAN M.A., EDRISS M.A., BASIRI M.R., 2006 - Analysis of colony and morphological characteristicistics in honey bees (Apis mellifera meda). - Pak. J. Biol. Sci. 9:2685-2688.
PAGE R.E., IBRAHIM M.M., LAIDLAW H.H., 1981 - The history of modern beekeeping in Egypt. - Glean Bee cult 109: 24-26.

RADLOFF S.E., HEPBURN R., BAGAY L.J., 2013 - Quantitative analysis of intracolonial and intercolonial morphometric variance in honeybees, Apis mellifera and Apis cerana. - Apidologie 34:339-351.

SAS, 2004 - The SAS System Version 9.1.3. SAS Institute, Cary, NC.

SHEPPARD W.S., SHOUKRY A., KAMEL S., 2001 - The Nile honey bee The bee of Ancient Egypt in modern times. - Am. Bee J. 141: 260-263. WADDINGTON K.D., 1989 - Implications of variation in worker body size for the honeybee recruitment system. - J. Behav. 2:91-103. 